Annals of Plant and Soil Research 23(3): 346-350 (2021)

https://doi.org/10.47815/apsr.2021.10082

\title{
Assessment of genetic variability, heritability and genetic advance of biparental progenies in okra [Abelmoschus esculentus (L.) Moench]
}

\section{J. JOHNNY SUBAKAR IVIN ${ }^{1}$ AND Y. ANBUSELVAM ${ }^{2 *}$}

\author{
[Department of Genetics and Plant Breeding, Faculty of Agriculture, Annamalai University, Chidambaram- 608 \\ 002, Tamil Nadu, India \\ Received: April, 2021: Revised accepted: June, 2021
}

\begin{abstract}
In the present investigation, the four cross combinations of Punjab Padmini $X$ Panruti local, Dharmapuri local X Panruti local, Punjab Padmini X Parbanikranthi and Dharmapuri local X Parbanikranthi and three bhendi populations, BIP, F2, and F3, were developed in 2019, and these populations were evaluated in 2020 to determine the extent of genetic variability, heritability, and genetic advance for twelve bhendicharacters. Significant variances in BIP compared to the population of F2 and F3 in most characters have been noted that showed high mean and wider variations in PCV and GCV in fruit length, number of fruits per plant and plant yield. High heritability of BIPS was revealed by Punjab Padmini x Parbanikranthi for the traits viz., days to 50 per cent flowering, number of fruits per plant, fruit length, fruit girth and fruit yield per plant which revealed the importance of additive gene action for these traits. This is indicative of both additive and non-additive gene action (dominance and epistasis). Hence, selection could not be practiced in the immediate segregating generations. These two characters also showed unfavourable association with fruit yield per plant in BIPs which indicated that all the unfavourable linkages were not broken down through intermating in the early segregating generation. Thus, selection should be postponed to later generations after intermating in one or two subsequent to obtain potential recombinants.
\end{abstract}

Keywords: Additive and dominance variance, epistasis, gene action, biparental progenies, genetic variability

\section{INTRODUCTION}

Okra [Abelmoschus esculentus (L.) Moench], is a mucilaginous content vegetable crop, and it contains $90 \%$ water, $2 \%$ protein and $7 \%$ carbohydrate and negligible in fat.Bhendi fruit has 88 per cent moisture, $41 \mathrm{kcal}$, protein $2.2 \mathrm{gm}$, carotene $58 \mathrm{mg}$, Fat $0.2 \mathrm{~g}$, thiamine 0.07 $\mathrm{mg}$, fibre $1.2 \mathrm{~g}$, niacin $0.6 \mathrm{mg}$, carbohydrates 7.7 $\mathrm{g}$, riboflavin $0.10 \mathrm{mg}$, calcium $0.09 \mathrm{~g}$, magnesium $43 \mathrm{mg}$, phosphorous $0.08 \mathrm{~g}$, ascorbic acid $16 \mathrm{mg}$, iron $1.5 \mathrm{mg}$, Sulphur $54 \mathrm{mg}$ and potassium $332 \mathrm{mg}$ per $100 \mathrm{~g}$ of fruit. (Montagnac et al. 2009). Okra is an annual shrub that is cultivated mostly within tropical and subtropical regions across the globe and represents a popular garden crop, as well as a farm crop (Meena et al. 2019). India is one of the highest producers of okra in the world, occupying an area of $526 \mathrm{~m}$ ha with a production of 6460 million tones and productivity of 15.0 metric tonnes/ha (Anonymous, 2019-2020a). In Tamil Nadu total area under vegetable crops is 374.46 thousand hectares with production of about 183.17 million tonnes and okra crop occupies area 19, 529 thousand hectares with production 1,75,237 tonnes and productivity of 8.97 tonnes/ ha (Anonymous 2020b). As, this crop has been used in all factors of human life starting from food to industry the demand for this crop is increasing substantially. (Khatiket al. 2013) This growing demand could be met up only through genetic manipulations which could favourably be done by increasing the productivity as there is only little scope for increasing the area under production. Selection of suitable breeding methodologies which involves suitable mating design for breaking down of undesirable linkages in the early segregating generations is a must (Xu et al. 2017). Many breeding methodologies suited the need and production of biparental progenies in the early segregating generation is one such approach which is most effective in breaking the undesirable linkages and in obtaining desirable recombinants. (Kumar et al. 2020) In view of the above facts, the current study aimed to compare the output of biparental progenies with the F2 generation of single and double cross populations of Bhendi. 


\section{MATERIALS AND METHODS}

The current study was conducted between January 2019 and December 2020 at the Department of Genetics and Plant Breeding, Annamalai University Chidambaram, using three biparental progenies, F2 and F3 populations of okra to determine the type and degree of genetic variability for vegetative and yield parameters. The four cross combinations are Punjab Padmini/ Panruti local, Dharmapuri local/ Panruti local, Punjab Padmini/ Parbanikranthi and Dharmapuri local/ Parbanikranthi. From each of the four cross combinations, $200 \mathrm{~F} 2$ plants were raised in non-replicated trail during January 2019 to April 2020 with a spacing of $60 \mathrm{~cm}$ between rows and $45 \mathrm{~cm}$ between plants. The F2 population was raised and the seeds were harvested to build up F3 generation. At the same time, enough F2 seeds were also retained for raising the $\mathrm{F} 2$ population during the next season for comparing F2, F3 and BIPS progenies. BIPs were obtained by intermating the randomly selected F2's as females and males. Recommended agronomic practices and need based plant protection measures were carried out. Four F2 plants selected randomly were designated as males. BIPs were developed by crossing each of these males to four plants selected as females. For the development of BIPs, the plants used as males and females were chosen at random, and no seed parent was used in more than one mating. The rest of the F2 plants after used in making BIPs were selfed by covering the flower with butter paper cover a day previous to anthesis. Selfed F2 plants (F3 seeds) were also harvested separately.

The F2 (200 plants) population was raised in non-replicated trail. The parents $(20$ plants), F3 (90 plants) seeds and intermated F2 (288 plants) were raised during June 2020 September 2020 in randomized block design with three replications and the chosen spacing was $60 \mathrm{~cm}$ between rows and $45 \mathrm{~cm}$ between plants. Observations like Days to 50 per cent flowering, Plant height, Internode length, Number of fruits per plant, Fruit girth, Fruit length and Fruit yield per plant were taken up. (Burton and Devane's 1953) methods were used to calculate the phenotypic and genotypic coefficient of variance. (Orokaet al.2016) and (Kumar et al.2019) methods were used to calculate heritability and genetic advance as a percentage of the mean.

\section{RESULTS AND DISCUSSION}

Through biparental mating, two or more partially balanced genotypes are brought through intermating which makes the change of reassembling maximum number of potentially functional genes and leads to the isolation of suitable, stable and widely adopted genotypes.( (Moose and Mumm, 2008). The Analysis of variance of BIPS indicated that there was significant difference among the ovule and pollen parent for almost all the traits in all the crosses studied.

\section{Mean performance}

The per se performance revealed that the BIPs of cross 3 recorded superior performance. The BIPs of Punjab Padmini/ Parbanikranthi recorded high mean performance for the traits viz., internode length, number of fruits per plant, fruit length, fruit girth and fruit yield per plant (Table 2). The superiority of BIPs over F3's was also noticed in all the crosses. General shift in the value of ranges for characters by following biparental approaches was also reported by Manickavelu et al. (2006) in rice. Hence, BIPs developed in all the four crosses could be used as base population for developing high yielding early maturity cultivars as they had combined superior performance for fruit yield per plant and earliness (Table 1). These finding were similar to the reported mean and range values by Maurya et al. (2019) for these traits in bhendi. The study of the components of variance of BIPs in all crosses showed that additive genetic variance was predominant which indicated that selection in the early intermingling generations could result in the development of potential progenies. 
Table: 1 Range and mean performance of Parents, F2's, F3's and BIPs for fruit yield per plant (g)

\begin{tabular}{ccccccccc}
\hline Parents & Generation & Cross 1 & Cross 2 & Cross 3 & Cross 4 & General Mean \\
\hline \multirow{2}{*}{ P1 } & Range & $230-298$ & $300-445$ & $232-300$ & $297-410$ & \multirow{2}{*}{321.06} \\
& Mean & 250.00 & $386.20^{* *}$ & 275.85 & $372.22^{*}$ & \\
P2 & Range & $210-280$ & $200-310$ & $219-319$ & $190-300$ & 257.39 \\
& Mean & 245.50 & 254.00 & $275.00^{* *}$ & $255.06^{*}$ & \\
F2 & Range & $210-633$ & $100-584$ & $305-505$ & $120-532$ & 424.42 \\
& Mean & $426.40^{*}$ & $439.26^{* *}$ & 422.00 & 410.05 & \\
F3 & Range & $210-287$ & $194-610$ & $300-525$ & $190-600$ & 413.04 \\
& Mean & $415.01^{*}$ & 410.08 & $422.10^{* *}$ & 405.00 & \\
BIPS & Range & $212-620$ & $102-620$ & $230-640$ & $120-600$ & 428.41 \\
\hline
\end{tabular}

${ }^{*}$ Significant at 5 per cent level; ** Significant at 1 per cent level

\section{Variability parameters}

Variability estimates helps us to choose potential crosses as it indicated the extent of recombination for effective selection. Effectiveness of the biparental approach was to create more variations than selfing. The usefulness of intermating, to create variability is largely dependent on aspects like genetic architecture and the nature of linkages among the genes controlling specific traits (Mcclosky and Tansksley 2013).

Table 2: Range and mean performance of Parents, F2's, F3's and BIPs for no. of fruits per plant (g)

\begin{tabular}{ccccccccc|}
\hline Parents & Generation & Cross 1 & Cross 2 & Cross 3 & Cross 4 & General Mean \\
\hline \multirow{2}{*}{ P1 } & Range & $22-29$ & $11-17$ & $23-30$ & $11-14$ & 14.86 \\
& Mean & $15.15^{\star}$ & 14.40 & $15.90^{* *}$ & 14.00 & \\
P2 & Range & $14-19$ & $12-19$ & $11-17$ & $13-20$ & 17.45 \\
& Mean & $21.00^{* *}$ & 15.51 & $17.20^{*}$ & 16.10 & \\
F2 & Range & $6-31$ & $6-28$ & $6-38$ & $6-25$ & 20.61 \\
& Mean & 19.25 & $22.10^{\star *}$ & 20.05 & $21.05^{\star}$ & \\
F3 & Range & $10-30$ & $23-51$ & $8-32$ & $21-50$ & 21.69 \\
& Mean & $24.10^{* *}$ & 20.22 & $23.00^{*}$ & 19.45 & \\
BIPS & Range & $7-24$ & $6-27$ & $10-29$ & $4-24$ & 22.45 \\
\hline
\end{tabular}

${ }^{*}$ Significant at 5 per cent level; ${ }^{* *}$ Significant at 1 per cent level

For fruit yield per plant, the variability studies revealed a high PCV and a moderate
GCV in BIPs Punjab Padmini/Parbanikranthi (Table 3).

Table 3: Variability parameters in F2's, F3's and BIPs for fruit yield per plant in Bhendi

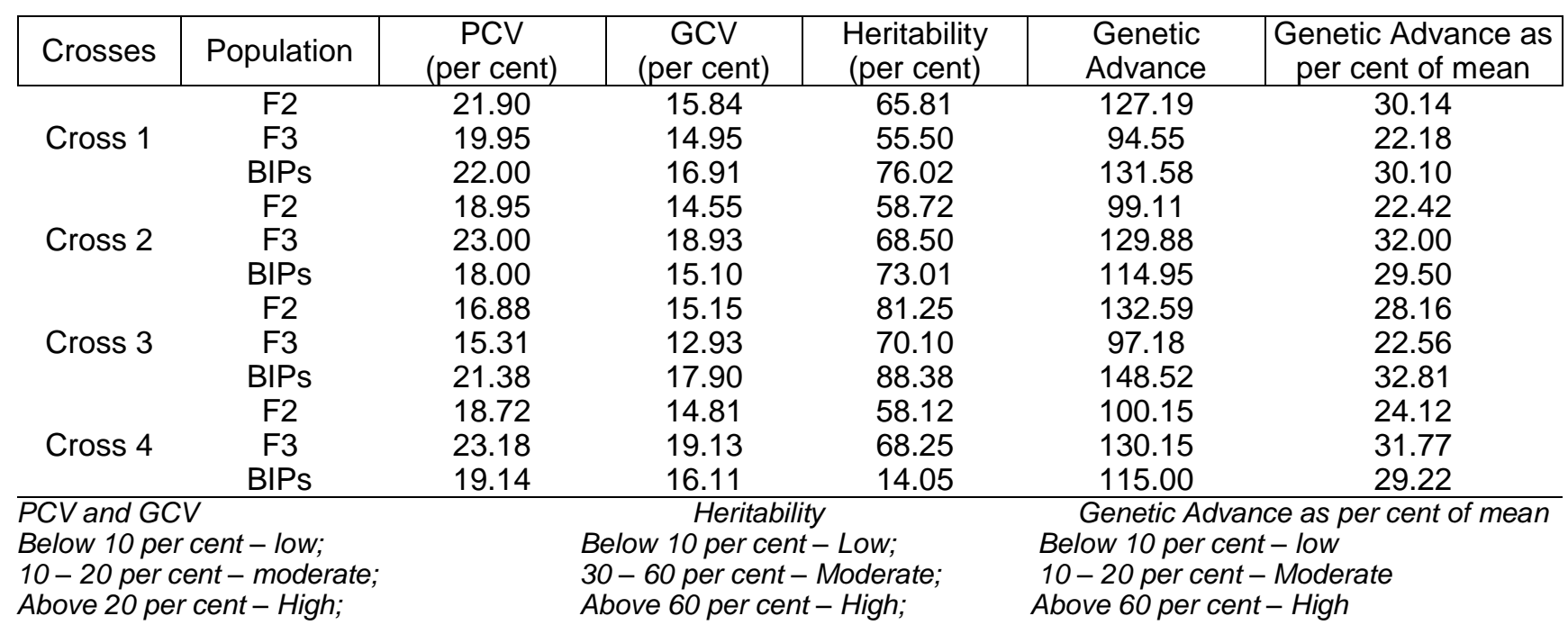


All the other traits recorded low to moderate PCV and GCV. Similar results were obtained by Oyetunde and Ariyo(2014) and for days to first flowering in 70 genotypes of bhendi. However, for almost all of the characters studied, BIPs recorded higher PCV and GCV values than F3s. Table 4 Variability parameters in F2's, F3's and BIPs for number of fruits per plant in Bhendi

\begin{tabular}{c|c|c|c|c|c|c|}
\hline Crosses & Population & $\begin{array}{c}\text { PCV } \\
\text { (per cent) }\end{array}$ & $\begin{array}{c}\text { GCV } \\
\text { (per cent) }\end{array}$ & $\begin{array}{c}\text { Heritability } \\
\text { (per cent) }\end{array}$ & $\begin{array}{c}\text { Genetic } \\
\text { Advance }\end{array}$ & $\begin{array}{c}\text { Genetic Advance as } \\
\text { per cent of mean }\end{array}$ \\
\hline \multirow{2}{*}{ Cross 1 } & F2 & 36.53 & 26.75 & 67.84 & 6.86 & 48.92 \\
& F3 & 30.17 & 25.72 & 67.85 & 6.59 & 3.89 \\
Cross 2 & F2 & 31.85 & 28.15 & 78.80 & 6.40 & 51.84 \\
& F3 & 32.38 & 26.73 & 63.99 & 5.46 & 44.73 \\
& BIPs & 25.57 & 19.52 & 65.61 & 5.69 & 33.00 \\
Cross 3 & F2 & 31.00 & 23.14 & 78.30 & 6.59 & 49.98 \\
& F3 & 27.42 & 22.65 & 51.10 & 5.65 & 33.70 \\
Cross 4 & BIPS & 28.97 & 18.65 & 46.19 & 3.59 & 25.50 \\
& F2 & 32.15 & 25.52 & 78.43 & 6.98 & 53.58 \\
& F3 & 26.19 & 18.18 & 62.16 & 5.32 & 40.31 \\
& BIPs & 27.94 & 23.36 & 44.59 & 4.49 & 24.53 \\
\hline
\end{tabular}

This variability in BIPs might be attributed due to breakage of linkage group obtained through intermating of the early segregating generations. For the traits of days to $50 \%$ flowering, number of fruits per plant, fruit length, fruit girth, and fruit yield per plant, high heritability and high genetic advance as a percentage of mean were observed in BIPs of Punjab Padmini/ Parbanikranthi, indicating the importance of additive gene action for these traits (Table 4). High heritability estimates in case of BIPs compared to selfed series were also reported by Parameshwarappa et al. (2009) in safflower and Raju et al. (2010) in Bhendi. The presence of lower to medium PCV and GCV, as well as high heritability and genetic advance as per cent of mean for these traits, suggested that both additive and non-additive gene action was present (dominance and epistasis). In general, BIPs showed its superiority over F3's. This may be presumed as due to the breakage of

\section{REFERENCES}

Ahsan, M. Z., Majidano, M.S. Bhutto, H. Soomro, A.W. Panhwar, F.H. Channa, A.R. and Sial, K.B. (2015). Genetic variability, coefficient of variance, heritability and genetic advance of some Gossypium hirsutum L. accessions. Journal of Agricultural Science, 7(2): 147.

Anonymous 2019-2020 Indian Horticulture database. National Horticultural Board, Government of India, Gurgoan, India. unfavourable linkages (Linkage in repulsion phase) and reunion of unfavourable genes in coupling phage. The association analysis also indicated that the characters such as plant height and number of fruits per plant showed positive significant association with fruit yield per plant in all the three crosses.

Thus, it may be concluded that intermating in F2 segregants increased the mean performance in BIPs than F3's. Analysis of variance also indicated the predominance of additive variance. Despite the fact that heritability and genetic advance are high, PCV and GCV are low to moderate for the majority of traits in Punjab Padmini/ Parbanikranthi. This meant that both additive and non-additive gene activity existed. As a consequence, acquiring possible genotypes would require one or two generations of intermating in the subsequent generation, followed by selection.

Burton, G.W., and Devane, D.E. (1953) Estimating heritability in tall fescue (Festuca arundinacea) from replicated clonal material. Agronomy Journal, 45 (10): 478-481.

Khatik, K., Chaudhary, R. and Khatik, C. (2013). 15 (1): 85-86 (2013) Heterosis studies in okra [Abelmoschus Esculentus (L.) moench]. Annals of Plant and Soil Research, 15(1): 85-86. 
Kumar, A., Kumar, M. Sharma, V. R. Singh, M. K. Singh, B. and Chand, P. (2019). Genetic Variability, Heritability and Genetic Advance studies in Genotypes of Okra [(Abelmoschus esculentus (L.) Moench]. Journal of Pharmacognosy and Phytochemistry, 8(1): 1285-1290.

Kumar, A., Sandhu, N. Venkateshwarlu, C. Priyadarshi, R. Yadav, S. Majumder, R. R. and Singh, V. K. (2020). Development of introgression lines in high yielding, semi-dwarf genetic backgrounds to enable improvement of modern rice varieties for tolerance to multiple abiotic stresses free from undesirable linkage drag. Scientific reports, 10(1): 1-13.

Manickavelu, A., Nadarajan, N. Ganesh, S. K. and Gnanamalar, R. P. (2006) Genetic analysis of biparental progenies in rice (Oryza sativa L.). Asian Journal of Plant Science 5 (1): 33-36.

Maurya, K. N., Pal, P. K. Asthana, G. Srivastava, A. and Shukla, S. (2019) Assessment of various genetic components through NCD-I and NCD-III designs of biparental mating in opium poppy. Journal of genetics 98: (1), 1-9.

McClosky, B., and Tanksley, S. D. (2013). The impact of recombination on short-term selection gain in plant breeding experiments. Theoretical and applied genetics 126(9): 2299-2312.

Meena, D. C., Meena, M. L. and Kumar, S. A. N. J. A. Y. (2019). Influence of organic manures and biofertilizers on growth, yield and quality of okra (Abelmoschus esculentus L. Moench). Annals of Plant and Soil Research, 21(2): 130-134.

Montagnac, J. A., Davis, C. R. and Tanumihardjo, S. A. (2009). Nutritional value of cassava for use as a staple food and recent advances for improvement. Comprehensive reviews in food science and food safety, 8 (3): 181194.

Moose, S. P., and Mumm, R. H. (2008). Molecular plant breeding as the foundation for 21st century crop improvement. Plant physiology, 147 (3): 969-977.

Oroka, F. O. (2016). Morphological and Yield Attributes of Okra (Abelmoschus esculentus L. Moench) as Influenced by Vermicompost+ NPK Nutrient Sources. Advances in life science and technology, 40: 46-50.

Oyetunde, O. A., and Ariyo, O. J. (2014) Genetics of seed yield and related traits in biparental crosses of okra, Abelmoschusesculentus (L.) Moench. Nigerian Journal of Genetics 28 (2): 8-14.

Parameshwarappa, K.G., Rudra Naik, V. and Bentur, M.G. (2009) Impact of biparental mating on genetic variability and path analysis in safflower. Karnataka Journal of Agricultural Science22 (1):4446.

Raju, C., Satish, R. G. Rajesab, R. G. Shanthakumar, G. and Anuluxmi, N. (2010). Genetic variability created through biparental mating in bhendi (Abelmoschus esculentus (L.) Moench). Gregor Mendal Foundation Journal 1: 33-35.

Xu, Y., Li, P. Zou, C. Lu, Y. Xie, C. Zhang, X., and Olsen, M. S. (2017). Enhancing genetic gain in the era of molecular breeding. Journal of Experimental Botany, 68(11): 2641-2666. 